\title{
The Jewish Study Bible
}

Adele Berlin and Marc Zvi Brettler, eds. New York: Oxford University Press, 2004. 2,143 pages.

Sable sur sable-c'est le livre de l'homme; blanche sur blanche-c'est le livre de Dieu.

Jabès' aphorism captures the challenge to readers of scripture: how to preserve the immaculate experience of the ineffable through a finite language of maculate perception. The Jewish Study Bible [JSB] is a testament to the human struggle with the divine as read through diverse interpretive lenses throughout the ages. Editors Berlin and Brettler, along with Fishbane, have compiled a first-rate Hebrew Bible that fuses the technically adept JPS English translation along with introductions, annotations, and essays by many of today's established and burgeoning scholars. This model is based upon The New Oxford Annotated Bible (p. xi), which abridges in-depth essays by contemporary scholars into accessible versions for general readers and undergraduate students. The balance between North American and 
Israeli scholarship is a sign of this volume's breadth and integrity. The JSB's symphony of voices is majestic in scope while accessible in execution.

Granted the space constraints imposed upon introductions and annotations, Sweeney's introductory notes on Ezekiel, when compared to Fishbane's recent JPS Commentary to the Haftorot, do not challenge conventional scholarship, which portrays Ezekiel as an eschatological priest. While the prophet receives and channels the divine word to the people and the priest cordons time-space in encountering the sancta not to be encroached, the mystic envisions the divine anthropos. The assumptions underlying Sweeney's introduction and annotations miss much of the poetics being read today as intrinsic to Ezekiel.

I will now address briefly the essays that make this volume a keepsake. My remarks will focus on what will likely strike the general reader as exceptional within this already outstanding volume of scholarship, which must be read in toto be appreciated.

In the "Modern Study of the Bible," the editors both abridge and expand the borders by encompassing the marginally normative within Biblical scholarship, for example, Latin American liberation theology (p. 2095a), feminist interpretation (p. 2095b), and canonical criticism (p. 2096). This is a welcome evolution in reading scripture, one that will speak to much broader audiences than merely the specialist or generalist.

Burgeoning scholarship is exemplified by the likes of Hindy Najman, who offers fresh introductions to texts like Ezra-Nehemiah as well as in her essay. Najman remarks how Ezra-Nehemiah's self-understanding as a reconstituted Second Temple community fulfilling the Abrahamic covenant and later prophecies is crucial to the recovery of textual memory in such a literary work incorporating the genre of memoir (p. 1669). She exposes Zunz's theological assumptions underlying the thesis of unified authorship (p. 1667), allowing for further polyphony surrounding the question of authorship. Her scholarship is coupled with the capacity for critical thinking and self-reflection that make even these introductory remarks stand out.

By comparison, her essay on "Early Nonrabbinic interpretation” (pp. 1835-44) introduces the reader to her new terminology, replacing the anachronistic and false category of "pseudo-epigrapha” with "self-effacing texts," namely, texts that rewrite and accompany traditions already regarded as authoritative (p. 1836). This is an example of the burgeoning scholarship that will revision the field and is a boon to the student of religion in general and scripture in particular. 
Responsible scholarship is also apparent in reading volatile books like Joshua, as proffered in Carol Myers' introduction. She stresses how Joshua is poised between an ideal and reality (p. 464) and exemplifies this in how scholars now read the total conquest as not entirely historical (p. 463), but rather as a literary-theological construct. By introducing a reality of Israelite settlement in the land rather than total conquest, Myers allows for a responsible contextualization.

Disconnected from the English-speaking world as a function of sparse translation, such renowned Israeli scholars as Avigdor Shinan, Uriel Simon, and Esther Eshel are finally available to the Anglophone generalist and specialist alike. Included in the section entitled "The Bible in Jewish Life and Thought,” Eshel’s essay “The Bible in the Dead Sea Scrolls” (pp. 1920-28) is a technical work of scholarship that is not compromised through distillation. In fact, it actually becomes more accessible to the general reader by cross-references to the section "Backgrounds for Reading the Bible," which includes Penkower's "The Development of the Masoretic Bible” (pp. 207783). Shinan's “The Bible in the Synagogue” (pp. 1929-937) correlates the Bible within the special matrix of the synagogue and shows how each is essential to the evolution of Judaism from the Second Temple period and beyond. Simon's “The Bible in Israeli Life” (pp. 1990-2000) is an outstanding analysis of Zionism's founding Biblical reading strategies and their contemporary cultural dissolution for the general reader and undergraduate student studying the Hebrew Bible in the diaspora.

Awareness of the poetic lens is evident in both Elliot R. Wolfson's "The Glorious Name and the Incarnate Torah” (pp. 1979-90) as well as in Adele Berlin's “Reading Biblical Poetry” (pp. 2097-2104). The uncharted territory here is in opening the general reader to Wolfson's presentation of how the Hebrew Bible is misread by the mystical Kabbalists.

Attention to the contemporary is evident in S. David Sperling's "Modern Jewish Interpretation” (pp. 1908-20) as well as the editors' adaptation of "Modern Study of the Bible." These essays span the Enlightenment until the recent publication of 'Etz Hayyim Humash, outlining its inherent problems and contributions to the field. Such a contextualization of the JSB within a trajectory of interpretation is a welcome and invaluable tool for the general reader.

Other invaluable tools for the general reader and undergraduate student are the appendices, including: "Weights and Measures" (p. 2105), "Timeline” (pp. 2106-09), “Chronological Table of Rulers” (pp. 2110-13), "Calendar” (p. 2114), “Table of Biblical Readings” (pp. 2115-17), and "Chapter/ 
Verse Difference” (pp. 2118-19), as well as the bibliographic "Translations of Primary Sources” (pp. 2120-21) and a superior “Glossary” (pp. 2122-42). These tools reflect the editors' recurring concern for pedagogy, a welcomed addition to the Study Bible market. Even though a volume of over 2,000 pages may seem daunting for any student to use beyond the confines of the library, this edition is no more imposing than a dictionary, with thin pages, clear print, and legible font size that make it a welcomed addition to the library and the back-pack, as we traverse white and sand.

Aubrey L. Glazer, Ph.D. Rabbi, Beth Tzedek Synagogue Toronto, Ontairo, Canada 